\title{
The nutritional status of nurses working shifts: A pilot study in Turkey
}

\author{
Estado nutricional de enfermeiras em regime \\ de trabalho por turnos: um estudo \\ piloto na Turquia
}

Semra NAVRUZ VARLI ${ }^{1}$

Saniye BILICI ${ }^{1}$

\section{A B S T R A C T}

\section{Objective}

This study was carried out to determine the nutritional status of shift-working female nurses at a university hospital in Ankara, Turkey.

\section{Methods}

A total of 110 volunteer female nurses ( $n=56$ control group, $n=54$ study group) were included in the study. A questionnaire with a three day food record collected the study data.

\section{Results}

The mean daily energy intake of the study group was higher than that of the control group (1756 $\pm 659 \mathrm{kcal}$ versus $1694 \pm 431 \mathrm{kcal}, p>0.05)$. While the carbohydrate intake $(196.3 \pm 85.5 \mathrm{~g}$ versus $185.9 \pm 54.7 \mathrm{~g})$ and fat intake $(79.5 \pm 29.5 \mathrm{~g}$ versus $77.1 \pm 22.6 \mathrm{~g})$ were higher in the study group, the protein intake was higher in the control group $(59.4 \pm 17.6 \mathrm{~g}$ versus $57.6 \pm 21.6 \mathrm{~g})$. The mean iron intake was statistically higher in the control group (10.6 $\pm 2.9 \mathrm{mg}$ versus $10.0 \pm 4.0 \mathrm{mg}, p<0.05)$.

\section{Conclusion}

To improve night shift workers' performance and nutritional status it is important to provide accessible, healthy, and quality food services.

Keywords: Female. Food habits. Night work. Nurses. Nutritional status.

\section{RE S U M O}

\section{Objetivo}

Este estudo determinou o estado nutricional de enfermeiras em regime de trabalho por turnos em hospital universitário em Ancara, na Turquia.

\footnotetext{
1 Gazi University, Faculty of Health Sciences, Department of Nutrition and Dietetics. Besevler, Çankaya, Ankara, 06500, Turkey. Correspondência para/Correspondence to: S NAVRUZ VARLI. E-mail: <semranavruz@gazi.edu.tr>.
} 


\section{Métodos}

Um total de 110 enfermeiras voluntárias ( $n=56$ no grupo controle e $n=54$ no grupo de estudo) participaram do estudo. Os dados do estudo foram coletados com o auxilio de um questionário com um registro alimentar de três dias.

\section{Resultados}

A ingestão de energia diária média do grupo de estudo foi maior que a mesma ingestão do grupo controle $(1756 \pm 659 \mathrm{kcal}$ versus $1694 \pm 431 \mathrm{kcal}, \mathrm{p}>0,05)$. Enquanto que as ingestões de carboidratos $(196,3 \pm 85,5 \mathrm{~g}$

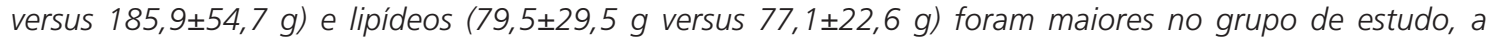
ingestão de proteínas foi maior no grupo controle $(59,4 \pm 17,6 \mathrm{~g}$ versus $57,6 \pm 21,6 \mathrm{~g})$. A ingestão média de ferro foi estatisticamente maior no grupo controle $(10,6 \pm 2,9 \mathrm{mg}$ versus $10,0 \pm 4,0 \mathrm{mg}, p<0,05)$.

\section{Conclusão}

Para melhorar o desempenho e estado nutricional de enfermeiras que trabalham no turno da noite é importante disponibilizar unidades de alimentação e nutrição saudáveis, acessíveis, e de qualidade.

Palavras-chave: Feminino. Hábitos alimentares. Trabalho noturno. Enfermeiros e enfermeiras. Estado nutricional.

\section{INTRODUCTION}

Shift work is defined as scheduled work that is completed outside the parameters of the traditional day shift, which is usually considered to be between 6.00 and $18.00^{1}$. Shift work is prevalent across the world. In the United States, approximately $15 \%$ of full time workers are shift workers employed across a wide variety of industries and, in Europe, the figure is $20 \%$. This number reaches $36 \%$ in China ${ }^{2,3}$ and, in Turkey, $8 \%$ of the working population is composed of shift workers ${ }^{4}$.

Shift work is associated with several health, social, and security problems possibly due to an impairment of biological rhythms and a negative working environment ${ }^{5}$. Studies have shown that problems, such as gastrointestinal diseases, body weight changes, cardiovascular diseases, negative eating habits, lack of exercise, excessive caffeine consumption, and smoking are more common among shift workers ${ }^{6-10}$. These problems may derive from disruption to physiological, psychological, and social circadian rhythms ${ }^{11}$.

As people work irregular hours, their daily routine is interrupted. Regular eating and sleeping habits are difficult to maintain ${ }^{12}$. A regular meal time helps maintain a stable order in the circadian system, but in the 24 hours working period, especially in night shift working, regular eating is frequently abandoned. Even if there is no definition of nocturnal life, delayed sleeping and eating, and the irregular meal times due to shift working are considered important circadian rhythm disruptors ${ }^{13}$. The interruption of regular eating habits is more common among shift workers, in particular, during night work. Although calorie intake remains substantially unaltered compared with the day shift, the quality, quantity, and frequency of food eaten by shift workers differ. On the night shift they usually have quick meals, consisting of fast food, and increase their intake of caffeinated drinks, such as tea and coffee ${ }^{14-16}$.

Night duty rotation is common practice in nursing. The nursing profession is staffed predominantly by women and has a work environment that is notable for its high work demands, and high levels of work stress and fatigue $^{17}$. The number of nurses in Turkey is the highest among health care workers and the profession requires shift work.

The present study was carried out to answer the following questions: Do energy and macronutrient intakes differ between day shift and night shift? Is there a statistically significant change in eating patterns between day shift and night shift? Are health problems more common in night shift workers?

This cross-sectional study was carried out in Gazi Hospital, Gazi University Health Research 
and Application Center, between March 2014 and September 2014 in Ankara, Turkey. The work schedule was categorized as follows. Day work was considered to be 8.00 to 16.00 , and shift work had to include being on duty between 16.00 and 8.00 at least four times a month. The shift work group had a work schedule between 8.00 and 16.00 except shift work turns. The monthly working hours of volunteer nurses included in the study was 40 hours.

The population of the study consisted of all nurses working in Gazi Hospital ( $n=824$ ). Although the sample size was calculated as 87 individuals with $95 \%$ reliability ( $\pm 5 \%$ deviation), it was targeted to reach more nurses. The shift work group consisted of 56 volunteer nurses, aged between 25 and 50 years, who had been shift working for more than one year. The day work group consisted of 54 nurses in the same age group who had been day working for more than one year. Pregnant nurses working day shift due to any health problem diagnosed by a doctor were excluded from the study.

\section{METHODS}

The questionnaire was completed by the researchers face to face with the participants and took approximately 25 minutes to be completed. The questionnaire consisted of general properties, health status, information about shift work and a three-day food consumption record. The three consecutive food consumption logs were recorded using 24-hour recall by a professional dietitian for the control group on two consecutive weekdays and one weekend day, and, for the shift work group, pre-shift, post-shift and during the shift. Average intakes of energy, macro-, and micronutrients were calculated using the software BeBiS 7.2 (Nutrition Information System, Istanbul, Turkey). The program and data are evaluated by a comparison with the Dietary Reference Intakes $(\mathrm{DRIS})^{18}$.

In the study body weight and height were measured by the researcher following the proper techniques ${ }^{19}$. Body Mass Index (BMI) was calculated by using the body weight/height ${ }^{2}\left(\mathrm{~kg} / \mathrm{m}^{2}\right)$ equation, and the World Health Organization (WHO) classification was used for evaluation ${ }^{20}$.

The level of physical activity was described as "sufficiently active" or "insufficiently active" with the help of a three-item short form used by Marshall et al. ${ }^{21}$. Also, the mean amount of daily sleep was investigated.

All statistical analyses were performed using the Statistical Package for the Social Sciences (SPSS, Inc., Chicago, Illinois, United States) version 20.0. Data were expressed as mean and standard deviation or frequency and percentage. Descriptive data were expressed as number and percentage distribution. Chi-square distribution was used in relational investigations. The statistical significance was set at 0.05 .

Participants were informed about the subject and the purpose of the study. Each nurse signed a voluntary participation form and filled in a questionnaire in accordance with the declaration of Helsinki (World Medical Association). This study was submitted to and approved by the Ethics Committees of Gazi University Faculty of Medicine (10/03/2014, Decision $n^{\circ}$ 135).

\section{RE S U L T S}

A total of 110 health workers (54 shift workers and 56 day workers) aged between 25 and 50 were included in the study. The mean age was $33.0 \pm 6.3$ years. The mean education level was $15.7 \pm 1.7$ years, while the mean employment duration was $11.2 \pm 7.2$ years. The shift workers' smoking rate $(39.3 \%)$ was significantly higher than that of day workers $(37.0 \%)(p<0.05)$. The mean daily smoking amount was $12 \pm 6.3$ cigarettes a day for a mean of $10.4 \pm 5.9$ years, while the majority of individuals (70.9\%) did not use alcohol.

The mean body mass index values of day workers and shift workers were $24.7 \pm 3.5 \mathrm{~kg} / \mathrm{m}^{2}$ 
and $23.8 \pm 3.4 \mathrm{~kg} / \mathrm{m}^{2}$, respectively, and no statistically significant difference between the groups was found ( $p>0.05)$.

In terms of physical activity, of all the individuals within the scope of the study, 10\% were "sufficiently active" while 90\% were "insufficiently active". No statistically significant difference was found between day workers and shift workers ( $p>0.05)$.

The study revealed that the mean sleep duration of the participants was $5.8 \pm 1.9$ and that the mean sleep duration of the day workers $(6.6 \pm 1.3 \mathrm{hrs})$ was significantly higher than that of shift workers (5.0 $\pm 2.1 \mathrm{hrs})(p>0.05)$.

Shift workers $(44.0 \%)$ reported more health problems than did day workers (37.0\%). The most common problems reported were digestive disorders, musculoskeletal system problems, polycystic ovary syndrome, diabetes, and mental disorders.

The mean daily number of main meals was $2.5 \pm 0.5$ and mean daily number of snacks was $1.9 \pm 0.8$. The total number of main meals per day was significantly higher for day workers $(2.8 \pm 0.5)$ than for shift workers $(2.3 \pm 0.5)(p<0.001)$. The majority of shift workers (69.6\%) skipped meals while only $22.3 \%$ of day workers skipped meals $(p<0.001)$.

The mean daily energy intake was higher for shift workers $(1756 \pm 659 \mathrm{kcal})$ than for day workers $(1694 \pm 431 \mathrm{kcal})(p>0.05)$. Shift workers' carbohydrate intake $(196.3 \pm 85.5 \mathrm{~g}$ and $185.9 \pm 54.7 \mathrm{~g}$, respectively) and fat intake (respectively $79.5 \pm 29.5 \mathrm{~g}$ and $77.1 \pm 22.6 \mathrm{~g}$ ) were higher while protein intake $(57.6 \pm 21.6 \mathrm{~g}$ and $59.4 \pm 17.6 \mathrm{~g}$, respectively) was lower than those of day workers (Table 1). The two groups did not differ in terms of protein, fat, and carbohydrate contributions to the daily energy intake (14.2 $\pm 3.1 \%$, $40.6 \pm 5.9 \%$ and $45.2 \pm 7.2 \%$, respectively, p>0.05).

The mean daily $B_{1}, B_{2}$, and $B_{6}$ vitamin intakes in both groups was similar while the mean daily intake of all other vitamins was higher for the day workers than for the shift workers, but the difference was not significant ( $p>0.05$ ). Except for the mean daily intake of calcium and sodium, the intakes of all minerals were higher in day workers than in shift workers (Table 1).

Table 1. Mean $(\bar{X})$, Standard Deviation (SD), Median (M) and Interquartile Range (IQR) of nurses' energy and nutrient intakes by working shift schedule.

\begin{tabular}{|c|c|c|c|c|c|c|c|c|c|c|c|c|c|c|}
\hline \multirow{2}{*}{ Energy and nutrients } & \multicolumn{4}{|c|}{ Day workers $(n=54)$} & \multicolumn{4}{|c|}{ Shift workers $(n=56)$} & \multicolumn{4}{|c|}{ Total $(n=110)$} & \multirow{2}{*}{$Z$} & \multirow{2}{*}{$p$} \\
\hline & $\bar{x}$ & SD & $\mathrm{M}$ & IQR & $\bar{x}$ & SD & $\mathrm{M}$ & IQR & $\bar{x}$ & SD & $\mathrm{M}$ & IQR & & \\
\hline Energy (kcal) & 1694.0 & 431.0 & 1668.0 & 376.0 & 1756.0 & 659.0 & 1664.0 & 660.0 & 1725.0 & 557.0 & 1664.0 & 558.0 & -0.23 & 0.816 \\
\hline Carbohydrates (g) & 185.9 & 54.7 & 181.7 & 82.3 & 196.3 & 85.5 & 178.7 & 79.4 & 191.2 & 71.9 & 179.9 & 81.1 & -0.22 & 0.820 \\
\hline Proteins (g) & 59.4 & 176 & 55.6 & 15.9 & 57.6 & 21.6 & 52.1 & 28.4 & 58.5 & 19.7 & 55.0 & 22.4 & -0.99 & 0.318 \\
\hline Fats (g) & 77.1 & 22.6 & 75.2 & 22.1 & 79.5 & 29.5 & 75.6 & 40.5 & 78.3 & 26.3 & 75.2 & 31.9 & -0.07 & 0.943 \\
\hline Saturated fatty acids (g) & 25.9 & 8.9 & 24.9 & 8.1 & 28.4 & 12.7 & 25.5 & 19.1 & 27.2 & 11.0 & 25.2 & 14.2 & -0.61 & 0.538 \\
\hline Vitamin $B_{1}(m g)$ & 0.8 & 0.2 & 0.8 & 0.4 & 0.8 & 0.3 & 0.8 & 0.3 & 0.8 & 0.3 & 0.8 & 0.3 & -1.39 & 0.163 \\
\hline Vitamin $B_{2}(\mathrm{mg})$ & 1.2 & 0.4 & 1.2 & 0.6 & 1.2 & 0.4 & 1.2 & 0.6 & 1.2 & 0.4 & 1.2 & 0.5 & -0.10 & 0.917 \\
\hline Niacin (mg) & 11.2 & 4.2 & 11.2 & 6.2 & 10.5 & 4.6 & 9.1 & 5.2 & 10.9 & 4.4 & 10.0 & 5.8 & -1.35 & 0.175 \\
\hline Vitamin $B_{6}(m g)$ & 1.3 & 0.4 & 1.3 & 0.6 & 1.3 & 0.5 & 1.1 & 0.5 & 1.3 & 0.5 & 1.2 & 0.6 & -1.63 & 0.101 \\
\hline Total folate $(\mu \mathrm{g})$ & 287.4 & 89.0 & 282.6 & 128.4 & 284.7 & 119.4 & 262.5 & 115.5 & 286.0 & 105.1 & 274.3 & 121.2 & -0.87 & 0.384 \\
\hline Vitamin $B_{12}(\mu \mathrm{g})$ & 4.1 & 4.6 & 2.9 & 2.1 & 3.5 & 2.7 & 2.7 & 2.6 & 3.8 & 3.7 & 2.8 & 2.4 & -0.27 & 0.783 \\
\hline Vitamin A $(\mu \mathrm{g})$ & 1130.01 & 1294.0 & 761.8 & 544.9 & 941.8 & 725.6 & 737.2 & 501.1 & 1034.2 & 1043.4 & 756.9 & 512.4 & -0.16 & 0.872 \\
\hline Vitamin D $(\mu \mathrm{g})$ & 3.0 & 7.5 & 0.6 & 0.8 & 1.6 & 3.5 & 0.8 & 0.9 & 2.3 & 5.8 & 0.7 & 0.9 & -0.49 & 0.618 \\
\hline Vitamin E (mg) & 18.4 & 6.5 & 18.8 & 6.4 & 17.9 & 8.0 & 17.1 & 9.5 & 18.2 & 7.3 & 18.2 & 8.3 & -0.77 & 0.439 \\
\hline Vitamin K $(\mu \mathrm{g})$ & 292.4 & 141.9 & 273.9 & 191.3 & 270.6 & 110.2 & 261.6 & 135.5 & 281.3 & 126.7 & 265.4 & 154.8 & -0.75 & 0.451 \\
\hline Vitamin C (mg) & 108.1 & 52.9 & 106.3 & 76.7 & 93.3 & 66.6 & 77.2 & 60.3 & 102.1 & 60.3 & 94.1 & 68.8 & -1.79 & 0.073 \\
\hline Iron (mg) & 10.6 & 2.9 & 10.7 & 5.0 & 10.0 & 4.0 & 9.7 & 3.0 & 10.3 & 3.5 & 9.8 & 4.0 & -1.95 & $0.049^{a}$ \\
\hline
\end{tabular}

Note: ${ }^{a} p<0.05$. 
The three-day evaluations of energy and nutrient intakes according to the DRIs are shown in Table 2. Energy, protein, and vitamin $\mathrm{B}_{1}, \mathrm{~B}_{2}, \mathrm{~B}_{6,}$ and $\mathrm{B}_{12}$ intakes meet the DRI standard of mean $82.18 \pm 26.56 \%, 106.34 \pm 35.83 \%$, $74.45 \pm 25.25 \%, 108.31 \pm 36.84 \%, 99.78 \pm 36.34 \%$, and $156.90 \pm 155.64 \%$, respectively. Also, calcium, iron, and vitamin C and D intakes meet the DRI standard of mean $56.14 \pm 22.22 \%, 57.22 \pm 19.52 \%$, $136.16 \pm 80.35 \%$, and $15.38 \pm 38.93 \%$, respectively.

Vitamin $C$ intake was adequate in shift workers (51.8\%) but excessive in day workers $(59.3 \%)$. Also, iron intake was more inadequate in shift workers $(85.7 \%)$ than in day workers $(66.7 \%)(p<0.05)$. There was no statistically significant difference between shift workers and day workers except for energy, vitamin $C$, and iron intakes ( $p>0.05$ ) (Table 3).

Most participants (99.1\%) eat away from home. Day workers frequently ate an afternoon meal $(90.6 \%)$, while shift workers frequently ate an evening meal (83.9\%). The frequency of eating at fast-food restaurants was higher in shift workers $(7.1 \%)$ than in day workers $(5.6 \%)$
( $p>0.05$ ) (Table 4). A total of $64.2 \%$ of the nurses eat away from home more than five times a week. Day workers eat away from home more often in a week than shift workers (5.5 times/week and 4.6 times/week, respectively) $(p<0.001)$ (Table 4).

\section{DISCUSSION}

One of the most important physiological problems attributed to shift work is the change in working, eating, and sleeping hours. The majority of the study individuals (94.6\%) stated that their nutritional status was affected, and over half the subjects (53.6\%) increased their food intake due to the changes in sleeping patterns during shifts. Previous studies have found that the quantity and frequency of food consumption in shift workers differed during the day. Night shift workers consumed meals in small quantities more than day workers during the day ${ }^{14-16,22}$. In this study the total number of main meals per day was significantly higher in day workers $(2.8 \pm 0.5)$ than in shift workers $(2.3 \pm 0.5)(p<0.001)$, and the majority of shift workers skipped meals, especially

Table 2. Evaluation of energy and nutrient intakes according to the Dietary Reference Intakes.

\begin{tabular}{|c|c|c|c|c|c|c|c|c|c|c|c|c|c|}
\hline \multirow{2}{*}{ Energy and nutrients } & \multicolumn{4}{|c|}{ Day workers $(n=54)$} & \multicolumn{4}{|c|}{ Shift workers $(n=56)$} & \multicolumn{4}{|c|}{ Total $(n=110)$} & \multirow{2}{*}{$p$} \\
\hline & $\bar{x}$ & SD & $\mathrm{M}$ & IQR & $\bar{x}$ & SD & $\mathrm{M}$ & IQR & $\bar{x}$ & SD & $\mathrm{M}$ & IQR & \\
\hline Energy (kcal) & 80.66 & 20.55 & 79.47 & 17.90 & 83.65 & 31.41 & 79.24 & 31.50 & 82.18 & 26.56 & 79.24 & 26.60 & 0.816 \\
\hline Proteins (g) & 108.08 & 31.93 & 101.13 & 28.90 & 104.68 & 39.45 & 84.70 & 51.60 & 106.34 & 35.83 & 100.0 & 40.70 & 0.318 \\
\hline Vitamin $B_{1}(m g)$ & 75.87 & 22.14 & 75.45 & 32.30 & 73.08 & 28.05 & 68.18 & 25.50 & 74.45 & 25.25 & 71.36 & 30.90 & 0.163 \\
\hline Vitamin $B_{2}(m g)$ & 108.48 & 36.82 & 104.54 & 49.80 & 108.14 & 37.18 & 109.09 & 51.40 & 108.31 & 36.84 & 106.81 & 49.10 & 0.917 \\
\hline Niacin (mg) & 80.33 & 29.81 & 79.89 & 44.10 & 75.21 & 32.82 & 64.82 & 37.00 & 77.72 & 31.34 & 71.73 & 41.60 & 0.175 \\
\hline Vitamin $B_{6}(\mathrm{mg})$ & 102.12 & 31.46 & 96.92 & 48.10 & 97.52 & 40.65 & 87.69 & 41.30 & 99.78 & 36.34 & 91.53 & 44.40 & 0.101 \\
\hline Total folate $(\mu \mathrm{g})$ & 71.85 & 22.25 & 70.64 & 32.10 & 71.17 & 29.84 & 65.61 & 28.90 & 71.50 & 26.27 & 68.58 & 30.30 & 0.384 \\
\hline Vitamin $B_{12}(\mu \mathrm{g})$ & 170.44 & 189.60 & 120.41 & 86.40 & 143.84 & 114.08 & 111.04 & 106.5 & 156.90 & 155.64 & 116.25 & 97.70 & 0.783 \\
\hline Vitamin C (mg) & 144.18 & 70.47 & 141.75 & 102.3 & 128.42 & 88.80 & 102.92 & 80.40 & 136.16 & 80.35 & 125.48 & 91.80 & 0.073 \\
\hline Vitamin A $(\mu g)$ & 161.42 & 184.85 & 108.83 & 77.80 & 134.54 & 103.65 & 105.31 & 71.60 & 147.74 & 149.05 & 108.13 & 73.20 & 0.872 \\
\hline Vitamin D $(\mu \mathrm{g})$ & 20.15 & 49.94 & 4.26 & 5.50 & 10.78 & 23.59 & 5.33 & 6.20 & 15.38 & 38.93 & 4.70 & 5.90 & 0.618 \\
\hline Vitamin E (mg) & 122.63 & 43.42 & 125.20 & 42.80 & 119.82 & 53.58 & 114.16 & 63.40 & 121.20 & 48.65 & 121.20 & 55.50 & 0.439 \\
\hline Vitamin K ( $\mu \mathrm{g})$ & 324.91 & 157.73 & 304.32 & 212.60 & 300.65 & 122.45 & 290.67 & 150.60 & 312.56 & 140.75 & 294.83 & 172.0 & 0.451 \\
\hline Calcium (mg) & 54.15 & 20.04 & 55.31 & 24.50 & 58.05 & 24.17 & 57.49 & 38.70 & 56.14 & 22.22 & 55.41 & 31.90 & 0.507 \\
\hline Phosphorus (mg) & 139.77 & 42.89 & 135.47 & 56.50 & 138.52 & 52.37 & 131.52 & 69.30 & 139.13 & 47.74 & 134.64 & 63.90 & 0.603 \\
\hline Magnesium (mg) & 76.81 & 25.20 & 72.29 & 28.80 & 71.15 & 30.21 & 65.47 & 20.10 & 73.93 & 27.88 & 67.01 & 25.90 & 0.063 \\
\hline Iron (mg) & 58.95 & 16.15 & 59.27 & 26.10 & 55.55 & 22.32 & 53.61 & 19.20 & 57.22 & 19.52 & 54.50 & 22.30 & 0.050 \\
\hline Zinc (mg) & 104.38 & 30.16 & 101.0 & 36.10 & 103.09 & 39.32 & 95.50 & 50.00 & 103.72 & 34.97 & 98.50 & 42.50 & 0.343 \\
\hline
\end{tabular}

Note: SD: Standard Deviation; M: Mean; IQR: Interquartile Range. 
Table 3. Evaluation of total daily energy and nutrient intake adequacy.

\begin{tabular}{|c|c|c|c|c|c|c|c|c|c|c|c|c|c|}
\hline \multirow{3}{*}{ Energy and nutrients } & \multicolumn{6}{|c|}{ Day workers $(n=54)$} & \multicolumn{6}{|c|}{ Shift workers $(n=56)$} & \multirow{3}{*}{$p$} \\
\hline & \multicolumn{2}{|c|}{$\begin{array}{c}\text { Inadequate } \\
(<67.0 \%)\end{array}$} & \multicolumn{2}{|c|}{$\begin{array}{c}\text { Adequate } \\
(67.0-133.0 \%)\end{array}$} & \multicolumn{2}{|c|}{$\begin{array}{c}\text { Excess } \\
(<133.0 \%)\end{array}$} & \multicolumn{2}{|c|}{$\begin{array}{c}\text { Inadequate } \\
(<67.0 \%)\end{array}$} & \multicolumn{2}{|c|}{$\begin{array}{c}\text { Adequate } \\
(67.0-133.0 \%)\end{array}$} & \multicolumn{2}{|c|}{$\begin{array}{c}\text { Excess } \\
(<133.0 \%)\end{array}$} & \\
\hline & $n$ & $\%$ & $\mathrm{n}$ & $\%$ & $n$ & $\%$ & $n$ & $\%$ & $n$ & $\%$ & $\mathrm{n}$ & $\%$ & \\
\hline Energy (kcal) & 11 & 20.4 & 42 & 77.8 & 1 & 1.9 & 16 & 28.6 & 36 & 64.3 & 4 & 7.1 & 0.662 \\
\hline Proteins (g) & 4 & 7.4 & 41 & 75.9 & 9 & 16.7 & 6 & 10.7 & 38 & 67.9 & 12 & 21.4 & 0.850 \\
\hline Vitamin $B_{1}(m g)$ & 17 & 31.5 & 36 & 66.7 & 1 & 1.9 & 26 & 46.4 & 29 & 51.8 & 1 & 1.8 & 0.120 \\
\hline Vitamin $B_{2}(\mathrm{mg})$ & 7 & 13.0 & 34 & 63.0 & 13 & 24.1 & 9 & 16.1 & 36 & 64.3 & 11 & 19.6 & 0.510 \\
\hline Niacin (mg) & 20 & 37.0 & 31 & 57.4 & 3 & 5.6 & 29 & 51.8 & 24 & 42.9 & 3 & 5.4 & 0.152 \\
\hline Vitamin $B_{6}(\mathrm{mg})$ & 7 & 13.0 & 35 & 64.8 & 12 & 22.2 & 11 & 19.6 & 36 & 64.3 & 9 & 16.1 & 0.261 \\
\hline Total folate $(\mu \mathrm{g})$ & 23 & 42.6 & 31 & 57.4 & - & - & 31 & 55.4 & 22 & 39.3 & 3 & 5.4 & 0.318 \\
\hline Vitamin $B_{12}(\mu \mathrm{g})$ & 11 & 20.4 & 25 & 46.3 & 18 & 33.3 & 11 & 19.6 & 22 & 39.3 & 23 & 41.1 & 0.518 \\
\hline Vitamin C (mg) & 9 & 16.7 & 13 & 24.1 & 32 & 59.3 & 9 & 16.1 & 29 & 51.8 & 18 & 32.1 & $0.028^{a}$ \\
\hline Vitamin A $(\mu \mathrm{g})$ & 6 & 11.1 & 29 & 53.7 & 19 & 35.2 & 8 & 14.3 & 30 & 53.6 & 18 & 32.1 & 0.631 \\
\hline Vitamin D $(\mu \mathrm{g})$ & 48 & 88.9 & 5 & 9.3 & 1 & 1.9 & 53 & 94.6 & 3 & 5.4 & - & - & 0.265 \\
\hline Vitamin E (mg) & 7 & 13.0 & 27 & 50.0 & 20 & 37.0 & 8 & 14.3 & 29 & 51.8 & 19 & 33.9 & 0.724 \\
\hline Vitamin $\mathrm{K}(\mu \mathrm{g})$ & - & - & 3 & 5.6 & 51 & 94.4 & - & - & 1 & 1.8 & 55 & 98.2 & 0.293 \\
\hline Calcium (mg) & 41 & 75.9 & 13 & 24.1 & - & - & 36 & 64.3 & 20 & 35.7 & - & - & 0.185 \\
\hline Phosphorus (mg) & - & - & 24 & 44.4 & 30 & 55.6 & - & - & 29 & 51.8 & 27 & 48.2 & 0.443 \\
\hline Magnesium (mg) & 22 & 40.7 & 30 & 55.6 & 2 & 3.7 & 33 & 58.9 & 20 & 35.7 & 3 & 5.4 & 0.091 \\
\hline Iron (mg) & 36 & 66.7 & 18 & 33.3 & - & - & 48 & 85.7 & 6 & 10.7 & 2 & 3.6 & $0.029^{a}$ \\
\hline Zinc (mg) & 5 & 9.3 & 41 & 75.9 & 8 & 14.8 & 7 & 12.5 & 38 & 67.9 & 11 & 19.6 & 0.853 \\
\hline
\end{tabular}

Note: ${ }^{a} p<0.05$.

Table 4. Distribution of away-from-home meals according to shift working.

\begin{tabular}{|c|c|c|c|c|c|c|}
\hline \multirow{2}{*}{ Away-from-home food intake habits } & \multicolumn{2}{|c|}{ Day workers $(n=54)$} & \multicolumn{2}{|c|}{ Shift workers $(n=56)$} & \multicolumn{2}{|c|}{ Total $(n=110)$} \\
\hline & $n$ & $\%$ & $\mathrm{n}$ & $\%$ & $n$ & $\%$ \\
\hline \multicolumn{7}{|l|}{ Eating away from home } \\
\hline Eats & 53 & 98.1 & 56 & 100.0 & 109 & 99.1 \\
\hline Does not eat & 1 & 1.9 & - & - & 1 & 0.9 \\
\hline \multicolumn{7}{|l|}{$\chi^{2}=1.047 ; p=0.306$} \\
\hline \multicolumn{7}{|l|}{ Meals eaten away from home ${ }^{\mathrm{a}}$} \\
\hline Breakfast & 27 & 50.9 & 8 & 14.3 & 35 & 32.1 \\
\hline Lunch & 48 & 90.6 & 21 & 37.5 & 69 & 63.3 \\
\hline Evening & 12 & 22.6 & 47 & 83.9 & 59 & 54.1 \\
\hline \multicolumn{7}{|l|}{ Eating out of home environment } \\
\hline Workplace cafeteria & 48 & 90.6 & 51 & 91.1 & 99 & 90.8 \\
\hline A la carte restaurant & 1 & 1.9 & - & - & 1 & 0.9 \\
\hline Kebab restaurant & 1 & 1.9 & 1 & 1.8 & 2 & 1.8 \\
\hline Fast-food restaurant & 3 & 5.6 & 4 & 7.1 & 7 & 6.5 \\
\hline \multicolumn{7}{|l|}{$\chi^{2}=1.152 ; p=0.765$} \\
\hline \multicolumn{7}{|l|}{ Frequency of eating away from home } \\
\hline Daily & 10 & 18.9 & 13 & 23.2 & 23 & 21.1 \\
\hline 2 times a week & - & - & 1 & 1.8 & 1 & 0.9 \\
\hline 3 times a week & - & - & 14 & 25.0 & 14 & 12.8 \\
\hline 4 times a week & 5 & 9.4 & 19 & 33.9 & 24 & 22.1 \\
\hline 5 times a week & 24 & 45.3 & 5 & 8.9 & 29 & 26.6 \\
\hline 6 times a week & 14 & 26.4 & 4 & 7.2 & 18 & 16.5 \\
\hline$\chi^{2}=41.511 ; p<0.001$ & & & & & & \\
\hline
\end{tabular}

Note: aMore than one response was received, and the percentages were calculated according to number. 
breakfast, for reasons such as feeling tired after the shifts and having brunch instead due to getting up late in the shift day.

In a prospective study by Knutsson et al. ${ }^{23}$, the frequency of consumption of high-carbohydrate snacks was higher in shift workers than in day workers. Another study found no statistically significant differences between day workers and shift workers in terms of energy and nutrient intakes ${ }^{24}$. In this study the mean daily energy and fat intakes were higher in shift workers than in day workers ( $p>0.05)$, but the mean daily protein intake was higher in day workers than in shift workers ( $p>0.05)$. A higher protein intake in day workers can be explained by the more frequent consumption of main meals. A lower mean number of main meals, despite the similarities in the mean amount of snack consumption in both groups, and the high consumption of high-fat and high-carbohydrate snacks during the night in shift workers results in higher energy, carbohydrate, and fat intakes. The ratio of saturated fatty acids and polyunsaturated fatty acids in the diet is a risk factor for cardiovascular disease, and the amount of energy from fat is considered an independent risk factor ${ }^{25}$. In this study the mean daily saturated fatty acid intake was higher in shift workers than in day workers.

Away-from-home consumption habits are increasing day by day. In this study almost all subjects $(99.1 \%)$ ate meals away from home. Shift workers often ate an evening meal (83.9\%) away from home while day workers often ate lunch (90.6\%) away from home, and most of them preferred to eat at their work places' food services. Thus, to improve night shift workers' performance and nutritional status, it is important to provide accessible, healthy, and quality food services.

Some behaviors for dealing with stress and staying awake for long working hours (smoking, high caffeine intake, eating more, etc.) can increase health risks. Shift work was defined as a risk factor for smoking habits ${ }^{26}$. In this study the proportion of smokers is significantly higher in shift workers $(39.3 \%)$ than in day workers $(37.0 \%)(p<0.05)$
Vitale et al. ${ }^{27}$ reported that irregular sleep was the most important reason for health problems among shift workers. In this study shift workers had more health problems than day workers, and sleep duration of shift workers was shorter. Regular physical activity contributes to the prevention and treatment of increased health problems resulting from exposure to shift work, and enables the individuals to acquire positive behavioral changes, thus helping to regulate the circadian rhythm ${ }^{28}$.

Griep et al. ${ }^{29}$ found that exposure to night shift was linked to an increase in BMI. No statistically significant difference was detected between the two study groups in terms of BMI. However, taking into consideration that the physical activity level of $90 \%$ of the study individuals was "insufficiently active", obesity prevention strategies, such as increasing physical activity, can improve the nurses' health status.

Finally, future studies would benefit from an examination of the 'night eating syndrome', especially in night shift workers, and from the use of a 'shift work index' for better evaluation of the overall health, sleep quality, and nutritional status of shift workers.

\section{CONTRIBUTORS}

S NAVRUZ VARLI: Data collection and/or processing, analysis and/or interpretation, literature search, writing and critical reviews; S BILICI: Concept, design, supervision, writing and critical reviews.

\section{RE FERE N CES}

1. Costa G. Factors influencing health of workers and tolerance to shift work. Theor Issues Ergon. 2003; 4(3-4):263-88.

2. Barger LK, Lockley SW, Rajaratnam SM, Landrigan CP. Neurobehavioral, health, and safety consequences associated with shift work in safety-sensitive professions. Curr Neurol Neurosci Rep. 2009; 9(2):155-64.

3. Demetriades $S$, Pedersini R. Working time in the $\mathrm{EU}$ and other global economies. Industrial relations in the EU and other global economies 2006-7. 
Luxembourg: Office for Official Publications of the European Communities; 2008.

4. Paoli P, Parent-Thirion A. Working conditions in the acceding and candidate countries. Dublin: European Foundation for the Improvement of Living and Working Conditions; 2013. [cited 2014 Dec 21] Available from: http://osha.Iv/en/news/news_ archive/eng/ef_report.stm

5. Puttonen S, Viitasalo K, Harma M. The relationship between current and former shift work and the metabolic syndrome. Scand J Work Environ Health. 2012; 38(4):343-8.

6. Arpaci F. Vardiya usulü çalişmanin hempirelerin sosyal yaşami ve ev yaşami üzerindeki etkilerinin incelenmesi. NWSA. 2007; 2(4):71-80.

7. Selvi Y, Özdemir PG, Özdemir O, Aydin A, Beşiroğlu $\mathrm{L}$. [Influence of night shift work on psychologic state and quality of life in health workers]. Düşünen Adam Psikiyatri ve Nörolojik Bilimler Dergisi. 2010; 23:238-43.

8. Lieuallen LM. The personality attributes of registered nurses who prefer to work night shift [master's thesis]. Spokane (WA): Gonzaga University; 2003.

9. Shandor AM. The health impacts of nursing shift work [master's thesis]. Mankato: Minnesota State University; 2012.

10. Leathert S. Health effects of internal rotation of shifts. Nurs Stand. 2000; 14(47):34-6.

11. Bambra CL, Whitehead MM, Sowden AJ, Akers J, Petticrew MP. Shifting schedules: The health effects of reorganizing shift work. Am J Prev Med. 2008; 34(5):427-34.

12. Folkard S, Spelten E, Totterdell P, Barton J, Smith L. The use of survey measures to assess circadian variations in alertness. Sleep. 1995; 18(5):355-61.

13. Garaulet M, Madrid JA. Chronobiological aspects of nutrition, metabolic syndrome and obesity. Adv Drug Deliv Rev. 2010; 62(9-10):967-78.

14. Esquirol $Y$, Bongard V, Mabile L, Jonnier B, Soulat JM, Perret B. Shift work and metabolic syndrome: Respective impacts of job strain, physical activity, and dietary rhythms. Chronobiol Int. 2009; 26(3):544-59.

15. de Assis MA, Nahas MV, Bellisle F, Kupek E. Meals, snacks and food choices in Brazilian shift workers with high energy expenditure. J Hum Nutr Diet. 2003; 16(4):283-9.

16. Sudo N, Ohtsuka R. Nutrient intake among female shift workers in a computer factory in Japan. Int J Food Sci Nutr. 2001; 52(4):367-78.

17. Winwood PC, Winefield AH, Lushington K. Workrelated fatigue and recovery: The contribution of age. J Adv Nurs. 2006; 56(4):438-49.
18. Otten JJ, Hellwig JP, Meyers DL. Dietary reference intakes: The essential guide to nutrient requirements. 2005 [cited 2014 Dec 23]. Available from: http:// www.nap.edu/catalog/11537/dietary-referenceintakes-the-essential-guide-to-nutrient-require ments

19. Lohmann TG, Roche AF, Martoel R. Human kinetics books anthropometric standardization reference manual. Champaign: Human Kinetics Books; 1998.

20. World Health Organization. BMI classification. Geneva: WHO; 2004. [cited 2016 Apr 21]. Available from: http://www.euro.who.int/en/health-topics/ disease-prevention/nutrition/ a-healthy-lifestyle/ body-mass-index-bmi

21. Marshall AL, Smith BJ, Bauman AE, Kaur $S$. Reliability and validity of a brief physical activity assessment for use by family doctors. Br J Sports Med. 2005; 39(5):294-7.

22. Lennernas MAC. Nutrition and shift work: The effect of work hours on dietary intake, meal patterns and nutritional status parameters (dissertation). Uppsala: Acta University; 1993.

23. Knutsson A, Andersson H, Berglund U. Serum lipoproteins in day and shift workers: A prospective study. Br J Ind Med. 1990; 47(2):132-4.

24. Theorell T, Akerstedt T. Day and night work: Changes in cholesterol, uric acid, glucose and potassium in serum and in circadian patterns of urinary catecholamine excretion: A longitudinal cross-over study of railway workers. Acta Med Scand. 1976; 200(1-2):47-53.

25. Ulbricht TL, Southgate DA. Coronary heart disease: Seven dietary factors. Lancet. 1991; 338(8773):985-92.

26. Biggi N, Consonni D, Galluzzo V, Sogliani M, Costa G. Metabolic syndrome in permanent night workers. Chronobiol Int. 2008; 25(2):443-54.

27. Vitale SA, Varrone-Ganesh J, Vu M. Nurses working the night shift: Impact on home, family and social life. J Nurs Educ Pract. 2015; 5(10):70-8.

28. Atkinson G, Edwards B, Reilly T, Waterhouse J. Exercise as a synchroniser of human circadian rhythms: An update and discussion of the methodological problems. Eur J Appl Physiol. 2007; 99(4):331-41.

29. Griep RH, Bastos LS, Fonseca MJ, Silva-Costa A, Portela LF, Toivanen $S$, et al. Years worked at night and body mass index among registered nurses from eighteen public hospitals in Rio de Janeiro, Brazil. BMC Health Serv Res. 2014; 14:603.

Received: November 27. 2015 Final version: April 19, 2016 Approved: May 2, 2016 